Monica Reichenberg

Professor ved Institutionen för språkstudier,

Umeå universitet

VISIONS

Conference

2011:

Teaching

\title{
Texter, läsförståelse och läsundervisning i Norge och Sverige - en översikt
}

— The most important thing about reading is comprehension (Pressley, 2002)

\section{Sammendrag}

I denna komparativa litteraturöversikt har jag jämfört norsk och svensk läsforskning. Detta mot bakgrund av resultaten i PISA 2009 . Svenska elevers läsförståelse har försämrats avsevärt och de allra svagaste läsarna har ökat $i$ antal. Så är inte fallet i Norge.

Det finns få svenska lässtudier som fokuserat mellanåren och högstadiet. Den svenska forskningen karaktäriseras vidare av den näst intill totala fokuseringen på skönlitterära texter. De norska forskarna har däremot riktat uppmärksamheten mot främst mellanåren och högstadiet, dvs. de år då antalet faktatexter intar en alltmer dominerande roll i skolarbetet och då svårighetsgraden på faktatexterna ökar.

Sverige har ingen institution som motsvarar det norska "Nasjonalt senter for leseforsking og leseopplcering”. På Lesesenteret har man utarbetat ett omfattande fortbildningsmaterial, som bygger på kompetensmålen i Kunnskapsløftet. Stora norska satsningar har också gjorts för att översätta läsdidaktisk forskning till skolpraktik. Några motsvarande svenska satsningar där man knutit så mycket forskarkompetens till sig finns inte.

\subsection{Problembeskrivning och syfte}

I den senaste PISA undersökningen, PISA 2009, framkom att norska elevers läsförståelse inte förändrats nämnvärt sedan 2000. Svenska elevers läsförståelse har däremot försämrats avsevärt. Försämringen gäller såväl hög- som lågpresterande elever. Men det är de allra svagaste som tappat mest under denna tioårsperiod. I Norge däremot har antalet svaga läsare sjunkit (Skolverket, 2010). Var femte svensk elev når idag inte upp till en nivå i läsning som är nödvändig för att kunna tillgodogöra sig annan kunskap. Hur har det kunna bli så här? ${ }^{1}$

I en forskningsöversikt (Granström \& Einarsson, 1995) framkom att undervisningen i den svenska grundskolan kännetecknades av en växling mellan lärar- 
ledda samtal i helklass och grupparbeten. Denna översikt studerade emellertid inte undervisning i läsförståelse specifikt. Till detta kommer att översikten har några år på nacken. Här finns således ett tomrum att fylla. Att göra en omfattande undersökning ute i klassrummen är dock förenat med vissa svårigheter. En mer framkomlig väg torde därför vara att undersöka forskarnas rön avseende undervisning i läsförståelse i bred bemärkelse. Det övergripande syftet är därför att undersöka norsk och svensk forskning rörande läsförståelse inom ämnena modersmål, svenska/norska som andraspråk, samhällsorienterande - och naturorienterande ämnen.

Mot bakgrund av syftet vill jag ha svar på följande frågor:

1. Vilka teoretiska ramverk har forskarna?

2. Vilka metoder har forskarna använt för att få reda på hur lärare undervisar i läsförståelse?

3. Vilka åldersgrupper har forskarna riktat in sig på?

4. Vilka texttyper har forskarna studerat?

5. Hur bedriver lärare undervisning i läsförståelse?

6. Vilka satsningar har gjorts i syfte att översätta läsdidaktisk forskning till skolpraktik?

Utifrån ovanstående forskningsfrågor kommer en komparativ litteraturöversikt att göras.

Givetvis torde det vara svårt att kunna göra en kausal inferens mellan forskning och elevers resultat på prov i läsförståelse. Sådana anspråk kommer inte heller att göras i denna studie. Däremot kommer jag att se vad för forskning som gjorts, hur undervisningen bedrivs samt vad för satsningar som gjorts. Därigenom torde det bli det möjligt att resonera om tendenser på ett meningsfullt sätt.

För att underlätta läsningen av denna forskningsöversikt har jag disponerat den enligt följande: Först kommer ett avsnitt om de informationskällor jag använt. Detta följs av en genomgång av de teoretiska ramverk och metoder som forskarna använt. Sedan följer ett avsnitt kring val av åldersgrupp och texttyp. Därpå uppmärksammas vilka satsningar som gjorts för att översätta läsdidaktisk forskning till skolpraktik. Avslutningsvis följer en slutdiskussion.

\subsection{Informationskällor}

För att få fram information har jag använt följande sökord: literacy, leseforståelse, leseundervisning, vurdering av tekst, läsförståelse, läsundervisning, läromedelsanalys, reading comprehension, textbook analysis, reading instruction. Jag har sökt på Svenska vetenskapsrådets (VR) projektdatabas samt 
Riksbankens jubileumsfond (RJ) över beviljade ansökningar kopplade till undervisning i läsförståelse från år 2000 och framåt. Vidare har jag sökt på Skolporten där svenska doktorsavhandlingar med inriktning mot undervisning presenteras samt i SLFFs forskningsbibliografi (Sveriges läromedelsförfattares förbund). När det gäller norska publikationer har jag letat i BIBSYS samt i DUO. Eftersom det kan vara en fördel att inte bara fokusera traditionella sökmotorer som ERIC, EBSCO och Google scholar, har jag därför också gjort sökningar i PsycINFO, Sociological abstract (CSA) och SAGE. Genom detta tillvägagångssätt kan man få en större variation och inte endast en renodlad bibliometrisk studie. Bibliometriska studier är däremot att föredra när man ska kartlägga sociala strukturer för vetenskapen (Hansen \& Lindblad, 2010). Givet mina forskningsfrågor är det mer kvalitativt orienterande frågor jag vill besvara.

I Skolverkets kunskapsöversikt (2007) framkom att flertalet svenska studier under perioden 1995-2007 undersökte antingen förskola eller gymnasium. Vidare var det den tekniska sidan av läsningen, avkodningen, som var i centrum för de flesta undersökningar. I denna studie kommer därför endast de studier att uppmärksammas som behandlar undervisning i läsförståelse i årskurserna 1-12. Följaktligen kommer (a) literacystudier i förskolan (b) studier rörande läsinlärning att lämnas utanför denna framställning. Det gör också (c) studier som publicerats före år 2000. Det är vid denna tidpunkt som RJ och VR börjar dela ut projektmedel (d) studier under licentiatnivå, såsom magister och masteruppsatser, lämnas också utanför. Däremot kommer licentiatuppsatser och doktorsavhandlingar att tas upp då de varit föremål för ingående granskning innan de publicerats.

För att artiklar och bokkapitel ska komma med har krävts att de varit utsatta för peer review. Det har varit förenat med vissa svårigheter att få reda på huruvida rapporter har varit utsatta för refereegranskning och därför har följande avgränsning gjorts. För att få komma med har normalt krävts att en av författarna är disputerad.

\subsection{Vilka teoretiska ramverk har forskarna använt?}

Det teoretiska fundamentet för att undersöka läsförståelse varierar såväl bland norska som svenska forskare. Följande teoretiska ramverk har kunnat urskiljas vad svenska forskare beträffar (a) sociokulturell teori (Molloy, 2002; Liberg m.fl., 2011), (b) en kombination av sociokulturell teori och socialsemiotisk modalitetsteori (Selander, 2010), (c) en kombination av sociokulturell teori och kognitivt psykologiskt perspektiv (Lundberg \& Reichenberg, 2011; Reichenberg, 2008a, b), (d) utbildningssociologi (Norlund, 2009) och (e) ett mediepedagogiskt fokus (Erixon, 2010). 
När det gäller norska forskare så är det teoretiska ramverket för Knain (2002), Løvland (2010) samt Skjelbred och Aamotsbakken (2010) en kombination av sociokulturell teori och socialsemiotisk modalitetsteori, för Andreassen (2008), Buch Iversen (2010) samt Bråten och Anmarkrud, (2011) m. fl. är ramverket en kombination av sociokulturell teori och kognitivt psykologiskt perspektiv.

Ett teoretiskt ramverk möjliggör respektive begränsar vad vi kan studera. Om vi exempelvis väljer ramverket $x$ får vi en uppsättning begrepp att nyttja i vår studie. Väljer vi ramverket y får vi en annan uppsättning begrepp (Kuhn, 1981). Följaktligen torde det teoretiska ramverket få implikationer för metodologiska beslut. Detta kommer jag bland annat att ta upp i nästa avsnitt.

\subsection{Vilka metoder har forskarna använt för att få reda på hur lärare undervisar i läsförståelse?}

Här kommer jag först att gå igenom de metoder som kunnat urskiljas för att sedan avsluta med hur de teoretiska ramverken förefaller ha påverkat de metodologiska besluten. Följande metoder har jag funnit: surveyundersökningar, survey med uppföljande videodokumentation, intervju eller enkät samt observationer. Observationerna kan i sin tur vara strukturerade eller ostrukturerade. Det kan också vara observation av egen undervisning (aktionsforskning). Vidare förekommer det interventionsstudier och intervjuer. Intervjuerna kan vara antingen halvstrukturerade eller ostrukturerade. Nedan kommer de använda metoderna att närmare granskas. Låt oss börja med surveyundersökningar. Exempel på sådana är PISA, PIRLS och de så kallade, Stockholmsundersökningarna. I de senare undersöktes läsförmågan hos elever i årskurs 3 i Stockholmsregionen mellan 1993 - 1999. Flera forskare har sedan använt delar av detta material och gjort fördjupade studier. Hit hör Fredriksson och Taube (2001) som undersökt de elever med invandrarbakgrund som ingick i studien. Damber (2010) har dessutom gjort en enkät och uppföljande intervjuer utifrån Stockholmsmaterialet. I "Testet under luppen" undersöker Liberg (pågående) och hennes kollegor hur man internationellt sett testar ungdomars kunskaper inom naturvetenskapliga ämnen.

Inom ramen för PISA gjorde man i Norge en studie, PISA+ som består av videodokumentation (Lie, Kjærnsli, Roe, \& Turmo, 2001). PISA+ hade följande mål:1) att förstå och tolka generella färdighetsnivåer och mönster i de norska PISA-resultaten 2) försöka förstå de pedagogiska processerna som bidragit till de norska PISA-resultaten och 3) komma med förslag på hur man kan omforma några av PISA-resultaten till konkreta förslag för att förbättra norsk utbildning och lärande i det livslånga lärandet.

I projektet ingick skolor som dels hade en modern pedagogisk orientering, dels en mer traditionell pedagogisk orientering. Datainsamlingen gjordes i norska, naturvetenskapliga ämnen och matematik. Som en del i detta projekt skrev Anmarkrud sin avhandling (2009). Hans studie fokuserar de pedagogiska 
processer som kan ha bidragit till resultaten i läsning i PISA-studien. Vad Sverige beträffar har inte någon liknande studie gjorts inom ramen för PISA.

\section{Observationer}

Observationer är en metod som används mycket inom såväl svensk som norsk läsforskning. Det är företrädesvis passivt deltagande observationer, dvs. där forskaren "sitter som en fluga på väggen”. Bland svenska forskare förekommer det också aktivt deltagande observation, dvs. forskarna observerar sin egen undervisning (Bommarco, 2006; Jönsson, 2007; Asplund, 2010).

När det gäller passivt deltagande har den dokumenterats via fältanteckningar och ljudinspelningar som ofta kompletterats med intervjuer/fotografier. Svenska forskare som gjort detta är Molloy (2002), Liberg (2004), Edling (2006), Ewald (2007), Lundström (2007), Knutas (2008), Schmidl (2008) och Stenlund (2011). Liberg (pågående) är också en av initiativtagarna till en forskarskola där ämnesspråk i naturvetenskap och matematik står i fokus. Syftet med forskarskolan är att ta reda på hur elever läser inom matematik och naturvetenskapliga ämnen, och hur det i sin tur påverkar inlärningen av ämnena.

Bland norska forskare kan nämnas Skjelbred och Aamotsbakken (2010) samt Løvland (2010).

Observationer har också gjorts med hjälp av videoinspelningar och intervjuer Svenska forskare som gjort detta är Thorson (2005), Reichenberg (2008a, b, 2010); Reichenberg och Wadbring (2008), Danielsson (2010), Asplund (2010), Tengberg (2011) och Tjernberg (2011) samt Lundberg och Reichenberg (2011).

Bland norska forskare ska uppmärksammas Anmarkrud (2009), Skjelbred och Aamotsbakken (2010) samt Helgevold (under arbete).

Till deltagande observation, även om det inte skett i ett klassrum, har också intervjuer och studier av artefakter räknats. Exempel på artefakter är läroböcker, datorer - inklusive power point - kartor etc. (Heyl, 2007; Wedin, 2006). Här finner vi följande svenska forskare: Mossberg Schüllerqvist (2008) och Norlund (2009) som kompletterat sina analyser med lärarintervjuer. Reichenberg (2000, 2008a, b) har studerat artefakter som en del av klassrumsobservationer.

Bland norska forskare hittar vi Knain (2002) som kompletterade sina läromedelsanalyser med elevintervjuer. Här kan också nämnas Skjelbred och Aamotsbakken (2010) samt Askeland och Aamotsbakken (2010).

Den som gör och analyserar observationerna är oftast läsforskaren själv. Men det finns ett undantag, nämligen projektet "Lesing av fagtekster som grunnleggende ferdighet i fagene” där läsforskare samarbetade med ämnesexperter i det aktuella ämnet vid observationerna och analyserna (Skjelbred \& Aamotsbakken, 2010, s. 12). Avsikten var att få in både textspecifikt och ämnesspecifikt i klassrummet. Sedan analyserades läroböcker och multimodala texter som forskarna sett i klassrummet. Vidare har man inom projektet intervjuat lärare, de elever som är goda läsare och skolledare. Eleverna blev intervjuade för att få belyst hur de arbetade med läromedel. En liknande svensk studie, dvs. där läs- 
forskare och ämnesforskare tillsammans analyserat läromedel och lektioner, har inte kunnat finnas.

\section{Interventionsstudier}

När det gäller interventionsstudier har jag hittat fler norska än svenska studier. Låt oss börja med de norska: Andreassen (2008), Andreassen och Bråten (2011) samt Buch Iversen (2010) Dessutom finns ett antal pågående interventionsstudier - doktorandprojekt - vid Lesesenteret i Stavanger, såsom Lise Helgevold m. fl.

Andreassen (2008) utvecklade en intervention med bakgrund i Reciprok undervisning, begreppsorienterad undervisning och transaktionell undervisning. Interventionen baserade sig på fyra principer och är i huvudsak genomförd under "samfunnsfaget" (Andreassen, 2008). Innan interventionen startade träffade Andreassen lärarna vid fem tillfällen. Vid dessa tillfällen gick han igenom de fyra principerna för interventionen. Under själva interventionsperioden träffade Andreassen lärarna vid två tillfällen. Andreassen hade också en kontrollgrupp som fick sin vanliga läs- och ämnesundervisning.

För att värdera effekten av interventionen bedömde Andreassen elevernas läsförståelse, strategibruk och läsmotivation före och efter undervisningen. Här fann dock inte Andreassen någon större effekt av interventionen. Vad elevernas strategibruk beträffar blev det en moderat effekt av den explicita strategiundervisningen. Det blev inte någon effekt av interventionen på elevernas läsförståelse och motivation. Eleverna i experimentgrupperna fick dock långt mer explicit strategiundervisning och var deltagare i fler lärandedialoger av hög kvalitet än eleverna i kontrollgruppen. I en uppföljningsstudie, som baserar sig på Andreassens avhandling, har Andreassen och Bråten (2011) gjort ytterligare analyser med hjälp av MANCOVA. Tre av lästesten fungerade som beroende variabler. Här fann Andreassen och Bråten en effekt på läsförståelsen hos de elever som hade fått explicit undervisning i läsförståelsestrategier.

Buch Iversen (2010) genomförde en interventionsstudie där hon undersökte effekter av inferensträning. Eleverna gick i årskurs 6. I studien användes texter och frågor som krävde att eleverna infererade. Träningen sköttes av elevernas lärare. Hon fann att de elever som fått undervisning i hur man infererar gjorde fler inferenser under själva läsningen än de elever som inte fått denna träning. De som fått inferensträning fick också en bättre läsförståelse. Rent teoretiskt visade Buch Iversens studie att undervisning i hur man infererar leder till framgång i läsförståelse något som, enligt Buch Iversen, bekräftar att inferenser bidrar till läsförståelse. Pedagogiskt visade undersökningen också att förmågan att inferera kan gynnas av undervisning via grafiska modeller.

I flera interventionsstudier har Reichenberg låtit elever träna efter programmet Questioning the Author (Beck et. al.,1996). Modellen går ut på att eleverna skall ifrågasätta textens författare när de läser. Den vill uppmärksamma eleverna på att författaren har ett stort ansvar när det gäller texters läsbarhet. En 
av studierna pågick under tre år. Eleverna gick i årskurs 4 när studien startade och gick ut årskurs sex när den slutade (Reichenberg, 2008a). Majoriteten av eleverna var svaga läsare. I studien ingick också kontrollgrupper. Under de första lektionerna var lärarnas samtalsturer långa och de frågor de ställde utgjordes mestadels av rena faktafrågor. Eleverna intog ett mycket passivt förhållningssätt. De ställde inga frågor och svarade kortfattat på lärarens. Under de strukturerade textsamtalen minskade lärarnas turlängder betydligt. Även lärarnas frågor ändrade karaktär, antalet faktafrågor minskade och istället ökade antalet inferens - och halvöppna frågor, dvs. frågor som vill få elever att reflektera över vad de läser. Vad eleverna beträffar intog de ett aktivt förhållningssätt, gick i närkamp med texten och gjorde åtskilliga såväl inferenser som reflektioner. Dessutom ifrågasatte de författarens auktoritet och initierade egna frågor.

Reichenberg och Wadbring (2008) har gjort en interventionsstudie med elever i årskurs 5. I denna studie var läsande av tidningstexter i fokus. Här ville forskarna också undersöka i vad mån lärarna uppmuntrade eleverna att vara mediekritiska. Resultaten är i överensstämmelse med dem i Reichenberg (2008a). Reichenberg (2008b) har också prövat modellen med elever i gymnasiets år 1. Då användes texter i samhällskunskap och omvårdnad. Majoriteten av eleverna utgjordes också i denna studie av svaga läsare. Samtalen visade att flera elever inledningsvis hade betydande svårigheter i att skapa mening i texterna, men att de tillsammans lyckades göra det. Resultaten är också här i överensstämmelse med Reichenberg (2008a) och Reichenberg och Wadbring (2008).

Lundberg och Reichenberg (2011) har i en studie låtit elever i grundsärskolan träna efter två olika modeller för strukturerade textsamtal. Hälften av eleverna fick träna efter Reciprok undervisning (RU) och hälften efter ett inferensträningsprogram (IT). Eleverna testades före och efter interventionen. Forskarna kunde konstatera att läsförståelsen ökade signifikant både hos de elever som övade enligt IT och de som övade enligt RU. De kvantitativa test som användes gav dock endast information om elevernas läsförmåga före och efter textsamtalen; testen gav däremot ingen information om hur det gick för eleverna under själva textsamtalen. Av den anledningen analyserades även textsamtalen. Eftersom en förutsättning för ett lyckat textsamtal är att samtliga elever får komma till tals, undersöktes också elevernas och lärarnas talutrymme på individnivå, dvs. hur många samtalsturer varje elev har i samtalet. Här kunde forskarna konstatera att läraren hade flest samtalsturer i början och att elevernas aktivitet ökade efter hand. Forskarna kunde också se att eleverna som övade enligt RU ställde egna frågor och reflekterade över innehållet i texterna. Eleverna hakade spontant på varandras inlägg och samtalen blev mer livaktiga.

Sammanfattningsvis har man alltså inom svensk läsforskning haft en preferens för intervjuer med lärare ofta $\mathrm{i}$ kombination med deltagande observation. Här har man framför allt varit ute efter lärarnas och elevernas 
erfarenheter när det gäller läsning och lärarnas upplevelser, tolkningar och syn på elevernas läsande samt elevernas upplevelser av sitt eget läsande. Detta är föga märkligt eftersom en tendens inom intervjustudier/etnografier är att fokusera på den mening deltagarna tillskriver olika händelser. Flertalet svenska läsforskare förefaller således använda teorin som ett sätt att tolka sina resultat.

Norska forskare har förvisso också efterfrågat lärares och elevers syn på läsning etc., men de förefaller ha relativt sett mer av formella och strukturerade klassrumsobservationer kombinerat med lärar- och elevintervjuer. De verkar främst ha varit ute efter att studera effekter respektive implikationer av lärares och elevers användning av exempelvis olika lässtrategier, något som kommer att studeras i ett senare avsnitt. Detta är föga förvånande eftersom man inom såväl kognitiv som sociokulturell forskning har varit intresserad av hur tänkandet aktualiseras genom tal om läsning respektive själva läsprocessen. Vidare finns det också en viss skillnad i förhållningssätt till kunskapssyn (epistemologi). Detta illustreras av det samarbete mellan textforskare och ämnesexperter som jag funnit i projektet "Lesing av fagtekster som grunnleggende ferdighet i fagene ”, något liknande svenskt samarbete har jag inte funnit.

Så här långt har vi således kunnat konstatera att val av metod och teori är något som läsforskare måste ta ställning till. Andra viktiga metodologiska överväganden som de måste göra är val av åldersgrupp och texttyp. Detta kommer att närmare belysas i nästa avsnitt.

\subsection{Vilka åldersgrupper och texttyper har forskarna riktat in sig på?}

När elever går i första och andra årskursen dominerar narrativa texter. Som tidigare uppmärksammats börjar svenska elever använda faktatexter i årskurs 3 och från årskurs 4 och framåt, dvs. på mellanstadiet och högstadiet ökar användningen av dessa texter. Samtidigt ökar också svårighetsgraden i dem (Lundberg \& Reichenberg, 2009). I vad mån har svenska och norska läsforskare uppmärksammat (a) elever på mellanstadiet och högstadiet i sina studier? (b) analys av faktatexter?

\section{Svenska forskare}

Elever i grundskolans lägre åldrar och gymnasieelever har varit föremål för flest svenska studier. Undantag är Lundberg och Reichenberg som har undersökt årskurserna 6-10 i grundsärskolan. Reichenberg (2008a), Reichenberg och Wadbring (2008) har undersökt mellanstadiet och Tengberg (2011), Molloy (2002), Mossberg Schüllerqvist (2008) och Schmidl (2008) har undersökt högstadiet.

De svenska forskarna har nästan uteslutande intresserat sig för skönlitterära texter (Brink, 2006; Molloy, 2002; Ullström, 2002; Thorson, 2005; Bergöö, 2005; Bommarco, 2006; Olin -Scheller, 2006; Ewald, 2007; Lundström, 2007; Mossberg Schüllerqvist, 2008; Schmidl, 2008; Asplund, 2010; Tengberg, 2011). Edling (2006), Liberg (2004) och Liberg m.fl. (2011) undersöker såväl fakta- 
texter som narrativa texter. Reichenberg har granskat texter i historia och samhällskunskap (2000, 2003, 2008ab, 2010). Hägerfelt (2004) har undersökt naturorienterande texter och Danielsson och Ekvall (2008) texter i kemi. Österholm (2004) har uppmärksammat texter i historia och matematik medan Selander lyfter fram texter i religion och filosofi (2010).

Lundberg och Reichenberg (2009) har dessutom i en forskningsöversikt listat vad som gör en text lättläst. När det gäller lärares val av texter har Lundström (2007) gjort en intressant observation, nämligen att det fanns stora skillnader i hur lärare talade om texturval och vad undervisningspraktiken uppvisade.

Vad har då svenska forskare uppmärksammat i sina textstudier? Flertalet svenska forskare har på ett eller annat sätt undersökt texternas tillgänglighet, dvs. i vad mån de innehåller läsförsvårande respektive läsunderlättande drag. Så har Norlund (2009) studerat tilltalet i två läroböcker i svenska på yrkesförberedande gymnasieprogram och två på studieförberedande program. Hon fann att böckerna på de två programmen skilde sig åt. På de studieförberedande programmen mötte eleverna uppgifter, redskap och instruktioner i läroböckerna. Instruktionerna var inte lika tydliga på de yrkesförberedande programmen. Däremot hade dessa böcker en informell ton och direkt tilltal. Norlunds slutsats blir att de elever som studerar på studieförberedande program blir väl förberedda för vidare studier till skillnad från de elever som studerar på yrkesförberedande program. Edling (2006) har undersökt graden av abstraktion och fann att den inte oväntat ökade i texter för högre skolår.

Reichenberg (2000) har granskat graden av kausalitet, dvs. i vad mån texterna utreder orsaks- och verkansamband och huruvida texterna genomsyras av en författarröst. Reichenberg bearbetade sedan två originaltexter, direkt tagna ur läroböcker, en i historia och en i samhällskunskap i tre olika textversioner. En fick en ökad grad av kausalitet, dvs. drag som underlättade för läsaren att se orsaks- och verkanssamband, en annan bearbetades med röst. I en text med röst talar författaren direkt till läsaren och vill därigenom närma texten till läsaren. Avsikten är att få läsarna att bli mer engagerade/aktiva. En tredje text bearbetades med såväl röst som kausalitet. Texterna var avsedda för år 7 . Det visade sig att den textversion som bearbetats med såväl kausalitet som röst hade en särskilt gynnsam effekt på andraspråksläsares läsförståelse.

Reichenberg har också undersökt om s.k. lättlästa texter verkligen gynnar den målgrupp de är avsedda för (Reichenberg, 2003). I en studie ingick 48 elever i årskurs 7 som fick läsa dels två texter tagna direkt från en lärobok i historia, samma texter tagna från en lättläst version av läroboken. Hälften av eleverna kunde avkoda förhållandevis väl, men de läste passivt. Den andra hälften hade stora problem med avkodningen. Elevernas förståelse ökade inte när de läste de lättlästa texterna. En förklaring som Reichenberg ger är att de lättlästa texterna var mycket korta och komprimerade. Författarna hade genomgående använt korta huvudsatser utan några kausala satskonnektorer som utredde orsaks- och verkansamband i texterna. Mycket av innehållet var 
implicit. De förenklade varianterna hade som en följd därav inte förenklats. Själva förenklingsproceduren hade istället medfört att inte bara förståelsen av viktiga tankeled försvunnit utan också rytmen i språket. Dessutom var det svårt att få fram engagemang i en så avskalad text.

\section{Norska forskare}

Skjelbred och Aamotsbakken (2010) har i sitt projekt "Lesing av fagtekster" undersökt högstadiet medan Andreassen (2008), Andreassen och Bråten (2011), Løvland (2010) och Buch Iversen (2010) undersökt mellanstadiet. I sitt doktorandprojekt undersöker Helgevold också mellanstadiet. Lie m.fl. (2001) har undersökt årskurs 9 liksom Anmarkrud (2009) och Anmarkrud och Bråten (2010), medan Knain (2002) har undersökt årskurs 10.

Norska forskare har inte haft samma ensidiga fokus på skönlitterära texter som svenska forskare utan här finns ett stort antal studier där faktatexter uppmärksammats: Knain (2002), Aamotsbakken, Askeland, Maagerø, Skjelbred och Torvatn (2005), Anmarkrud (2009) Anmarkrud och Bråten (2010), Andreassen (2008), Samuelstuen (2005), Samuelstuen och Bråten (2005), Andreassen och Bråten, (2011), Bråten, Strømsø, och Britt (2009), Løvland (2010), Maagerø och Seip Tønnessen (2006), Eikeland (2001), Hvistendahl (2004a, b), Maagerø och Skjelbred (2010), Askeland (2008), Seip Tønnesen (2010), Skjelbred och Aamotsbakken (2010) samt Siljan (2011).

I likhet med de svenska forskarna har de norska på olika sätt uppmärksammat texternas tillgänglighet. Bråten och Samuelstuen (2005) har undersökt om förkunskaper om det ämne som behandlas i texten påverkar förståelsen av texten. De fann att så var fallet. Askeland har undersökt bruket av metaforer (2008) och Torvatn (2002) hur den språkliga utformningen påverkar förståelsen. Siljan (2011) visar hur nominaliseringar spelar en viktig roll när olika termer ska bildas i faktatexter. Hon visar också att de kan vara ett värdefullt redskap när det gäller att organisera information i texten på ett varierat och kreativt sätt. Aamotsbakken m.fl. (2005), Aamotsbakken och Askeland (2010) har undersökt läromedlens tillgänglighet för minoritetselever. De fann att läroböckerna inte bara är svåra för minoritetselever utan också för elever med norska som förstaspråk. Om eleverna inte kan känna igen sig i innehållet, har de svårt att skapa mening i det lästa. Kan de däremot känna igen sig blir det lättare. Aamotsbakkens och Askelands slutsats är att lärarna måste ta sig tid att tillsammans med eleverna arbeta med texterna.

I sitt projekt undersökte Skjelbred och Aamotsbakken (2010) läromedel i matematik, norska, naturvetenskapliga ämnen och RLE utifrån vilken grad de tillvaratar grundläggande färdigheter främst i läsning. De har speciellt studerat vilken roll läsaren - i det här fallet eleven - tilldelas och vilken textkompetens läromedlet förutsätter och vidareutvecklar i förhållande till olika läsare. Dessutom har de studerat det ämnesspecifika språket med fokus på multimodalitet och språklig tillgänglighet. 
Sammanfattningsvis kan konstateras att svenska forskare med några få undantag riktat in sig på skönlitterära texter. I Norge har man däremot inte haft detta ensidiga fokus utan här har forskarna undersökt såväl skönlitterära texter som faktatexter. Vidare har såväl norska som svenska forskare varit intresserade av läromedlens tillgänglighet.

Det räcker dock inte med att studera texternas tillgänglighet eftersom en text inte kan stå på egna ben. Eleverna behöver också få undervisning i läsförståelse. De svenska och norska forskarnas rön avseende undervisning i läsförståelse kommer jag att redogöra för i nästa avsnitt.

\subsection{Hur bedriver lärare undervisning i läsförståelse?}

Studier har visat att såväl svaga som goda läsare gynnas av strukturerad undervisning. Forskningen har också uppmärksammat vikten av att utmana eleverna i den närmaste utvecklingszonen och att lärande i grupp är gynnsamt (Wasik \& Slavin, 1993; Nystrand, 1997; Reichenberg, 2008a, b; Lundberg \& Reichenberg, 2011 ). En viktig fråga är om den didaktiska forskningen får genomslag i skolpraktiken. Här kommer vi först att granska de svenska studier som gjorts rörande lärares undervisning i läsförståelse för att sedan gå in på de norska.

\section{Svenska klassrum}

Resultaten är nedslående när det gäller undervisning i läsförståelse. "Fri”, dvs. ostrukturerad upplevelseläsning av bänkböcker och "recensionsskrivande" dominerade i de klassrum Ewald (2007) observerade. Ambitioner till en mer reflekterad litteraturpedagogisk hållning förekom som spridda öar i läskulturerna (Ewald, 2007). Liknande resultat fann Knutas (2008). Han genomförde 108 lektionsobservationer. Under hela den tid Knutas besökte lektionerna fördes inte vid något tillfälle några längre samtal kring gemensam läst skönlitteratur. Eleverna läste hela skönlitterära verk men dessa diskuterades aldrig i klassrummet. Den språkliga delen av svenskundervisningen tog sig främst uttryck i att eleverna lämnade sina uppgifter till lärarna som sedan gav dem respons på dessa. Undervisningen var med andra ord starkt individualiserad. Ett stort ansvar lades på eleverna själva.

Också lärarna i Schmidls studie lade ett stort ansvar på eleverna (2008). Schmidl fann att eleverna inte fått några litterära verktyg för berättarteknik eller för att kunna analysera och förstå hur en text är uppbyggd. En av klasserna läste Jack Londons Skriet från vildmarken och vissa elever förstod först långt in i boken att det handlade om en hund. De hade också svårt att förstå bokens slut. Många elever gjorde, enligt Schmidl, personligt knutna tolkningar, men i skolan måste man, menar Schmidl, kunna gå utöver det som rör ens egen person. Man måste lära sig att relatera till andra texter och till omvärlden - det var det många som inte kunde. 
Också Molloy (2002) fann att det var svårt att ha samtal i klasserna då flickorna i många fall avstod från att delta av rädsla för kommentarer från andra elever. Vidare uppmärksammar Molloy att eleverna inte själva fick välja böcker utan de läste de böcker som deras lärare valt. Även Stenlund konstaterar (2011) att eleverna endast i begränsad omfattning fick möjlighet att utveckla sin avkodningsförmåga och en djupare förståelse av texter. Olin Scheller (2006) fann att eleverna i gymnasieskolan inte får tillräckligt stöd i att utveckla kunskaper i att läsa, tolka och kritiskt förhålla sig till texter av olika slag. Även i lärarenkäten i PIRLS (Rosén, Myrberg, \& Gustafsson, 2005) framkom att tyst enskild läsning var en daglig aktivitet för de allra flesta. Det var ovanligt att eleverna fick öva sig att generalisera. De vanligaste läsförståelseaktiviteterna i Sverige var att eleverna fick visa att de förstått lästa texter genom att " visa eller förklara vad de menar" och att identifiera huvudbudskapet (s. 271). Det var också relativt vanligt att de fick identifiera huvudbudskapet i texter och jämföra med egna erfarenheter. Forskarna konstaterar vidare att samtal om texter inte var särskilt utbrett i Sverige. De uppmärksammar också att svenska elever inte erbjöds särskilt mycket undervisning i reflektion och analys av texter. Vidare konstaterar de att skönlitteratur, i olika former såsom sagor, lyrik och pjäser hade en framträdande roll i läsundervisningen. Det var mer ovanligt att svenska elever fick beskriva stil och struktur i en text än vad elever fick göra internationellt. Att sammanfatta texter muntligt eller samtala med varandra om texter var betydligt vanligare i internationella sammanhang än i Sverige.

Ovanstående studier har främst fokuserat undervisning i svenska, men resultaten är lika nedslående i den studie Edling (2006) gjorde. Hon fann att i synnerhet inom de samhällsorienterande och naturorienterande ämnena syftade en majoritet av aktiviteterna i klassrummet till att reproducera kunskap på ett monologiskt sätt, snarare än att producera kunskap dialogiskt (Edling, 2006) . Inte heller Danielsson (2010) fann att det förekom särskilt mycket arbete med att eleverna skulle få en djupare förståelse av kemitexterna som de var satta att läsa.

Två studier visar på positiva resultat. En av dem är Mossberg Schüllerqvists (2008). I hennes intervjuer berättade lärarna att de arbetade både med litterär analys och med att knyta läsningen till elevernas verklighet, dvs. läsa verkligheten. De fokuserade på att lära eleverna litterär kompetens och få dem att se den litterära textens mångfaldiga meningserbjudande. Mossberg Schüllerqvist kompletterade dock inte sina intervjuer med observationer i klassrummet (Mossberg Schüllerqvist, 2008). Tjernberg (2011) gjorde ett medvetet urval då hon valde att endast studera "expertlärare, dvs. lärare som var kända för att bedriva framgångsrik undervisning. Hon fann att framgångsrika lärares undervisning kännetecknas av struktur på olika nivåer, balans mellan form och funktion, hög grad av utmanande arbetsuppgifter samt att lärandet synliggörs. Det specialpedagogiska perspektivet framträdde genom att lärarna arrangerade pedagogiska situationer där en stor variation av förmågor fick komma till uttryck och växa. 


\section{Norska klassrum}

De norska resultaten i PISA 2000 var nedslående och ledde till en rad åtgärder inom utbildningsområdet. En sådan var att ge den amerikanska läsforskaren Rasmussen i uppdrag att utreda hur det hade kunnat bli så här. Rasmussen (2003) analyserade utbildningspolitiska dokument, gjorde klassrumsobservationer och hade halvstrukturerade intervjuer med norska läsforskare, förskollärare, lärare i grundskolan och rektorer. En av hans slutsatser var att norsk undervisning varit bra på att undervisa hur barn lär sig läsa. Däremot hade det inte förekommit mycket undervisning i läsförståelse. Ett annat problem var att man i undervisning arbetat så lite med faktatexter (expository texts). Rasmussen kom med förslag på åtgärder som skulle kunna leda till att läsförståelsen ökade hos norska elever. De åtgärder han föreslog var: ökad fokus på metodik i lärarutbildningen, och ökad satsning på åtgärder som syftar till att främja läsmotivationen hos eleverna. Det kan ske genom att lärare tänker på att välja spännande texter för att öka elevernas läsengagemang. Vidare anbefallde han explicit undervisning i lässtrategier. Denna undervisning borde enligt Rasmussen fokuseras mot en repertoar av lässtrategier med dokumenterad effekt. Vidare bör denna undervisning pågå under hela skolåret. Ett resultat av Rasmussens studie blev Kunnskapsløftet 2006 och den stora satsningen på läsning i alla ämnen.

En annan studie som kom samma år var Solheim och Tønnesens (2003). De gjorde en analys av 20 klasser med de bästa resultaten på PIRLS undersökningen och jämförde med 20 klasser med de svagaste läsresultaten i PIRLSundersökningen. De fann att över $80 \%$ av lärarna i klasser med bäst resultat rapporterade läsupplärning eller läsaktiviteter varje dag. I dessa klasser verkade läsningen ha karaktär av en social aktivitet. Eleverna läste ofta högt för varandra. I de klasser med svagast resultat använde sig lärarna i stor omfattning av skriftliga uppgifter i arbetsböcker. Hälften av lärarna tillstod att de aldrig bedrev någon strategiundervisning. Den andra hälften bedrev strategiundervisning 1-2 gånger i månaden.

Anmarkrud (2009) undersökte i sin deskriptiva klassrumsstudie fyra lärares läsundervisning i klassrummet. Analysen av observationsdata visade att strategiundervisningen huvudsakligen var av implicit karaktär. Nästan $2 / 3$ av den observerade undervisningen i lässtrategier försiggick som implicit strategiundervisning. Bara $6.1 \%$ av den totala strategiundervisningen försiggick som explicit strategiundervisning. Explicit uppmaning att använda strategier förekom endast i $10 \%$. Bara två strategier användes i den explicita strategiundervisningen, memoreringsstrategier och organiseringsstrategier.

Skjelbred och Aamotsbakken (2010) såg i sina studier få samtal kring texter i läroböcker. Däremot såg forskarna att lärarna arbetade mycket med elevmotivation och att sätta in teman i sitt sammanhang. Vidare observerade de att lärarna arbetade inkluderande genom att minoritetsspråkliga elever hade samma 
läromedel som övriga elever i klassen och att de minoritetsspråkliga eleverna fick mer uppmärksamhet när det gäller läsning än majoritetsgruppen.

Knudsen och Mortensen Buan (2010) observerade elever i andra, femte och åttonde årskursen under två veckor. Gemensamt var att det oftast förekom kollektiva lärarledda genomgångar innan själva läsningen började i alla de tre årskurserna. Lärarna förberedde eleverna på den individuella läsningen genom att kontrollera deras förkunskaper. Det kunde ske genom repetition av vad de läst tidigare och eleverna fick ofta möjlighet att komma med egna reflektioner. När det gällde uppgifter i anslutning till lärobokstexterna förekom det samtal kring dem och vad det innebar att skriva med egna ord (årskurs 5). Lärarna anpassade undervisningen för svaga elever och elever som behövde stöd på ett eller annat sätt.

Lärarna i Løvlands (2010) studie undervisade också i lässtrategier. Løvland konstaterar "Sjølv om dette ikkje er ei kvantitativ undersøking, har eg eit klart inntrykk av at ein stadig legg meir vekt på strategiutvikling i fag som RLE, samfunnsfag og naturfag”. Løvlands observationer sträckte sig över två skolår. Løvland drar slutsatsen att Kunnskapsløftet starka fokusering på läsning har "blitt ein del av den literacypraksisen som kjenneteiknar arbeidet i skolen".

Møller, Ottesen och Hertzberg (2010) intervjuade lärare och rektorer på tio skolor - sex grundskolor och fyra gymnasieskolor. De fann en skillnad mellan skolformerna. I grundskolorna fanns skolor som satsade på läslärare medan det i gymnasieskolorna satsades främst på att hjälpa elever med läs- och skrivsvårigheter, dvs. de svagaste läsarna, elever med ett annat förstaspråk än norska samt elever på yrkesprogram. Vidare menade de intervjuade lärarna att läsning, skrivning och muntliga färdigheter hade skolan alltid arbetat med.

Ett återkommande dilemma för såväl utbildningsvetenskaplig forskning som läsforskning är att nå ut med sina resultat i klassrummen. Detta brukar ibland kallas för implementeringsproblematiken. Hur man i Sverige och Norge hanterat detta kommer jag att ta upp i nästa avsnitt.

\subsection{Vilka satsningar har gjorts i syfte att översätta läsdidaktisk forskning till skolpraktik?}

Låt oss börja med att se vilka strategier man använt i Norge för att överföra vetenskapliga resultat till skolpraktiken. Därefter fortsätter vi med Sverige.

\section{Norska strategier}

I efterdyningarna av PIRLS 2001 har läsundervisning fått stort fokus i norsk lärarutbildning och forskning. I PIRLS 2001 visade det sig att $51 \%$ av de norska lärarna svarade att de aldrig eller nästan aldrig undervisade i läsförståelse. Bara $1 \%$ av lärarna svarade att de undervisade i strategier varje dag (Solheim \& Tønnesen, 2003; Van Daal m.fl., 2007). 
Det har gjorts omfattande satsningar för att dels möjliggöra forskning kring läsförståelse dels översätta dessa resultat till skolpraktiken: Här skall särskilt lyftas fram "Gi rom for lesing!" Strategi for stimulering av leselyst och leseferdighet 2003-2007”. Det är en nationell handlingsplan som är antagen av Utdannings- og forskningsdepartementet. Någon sådan nationell handlingsplan har aldrig antagits i Sverige. I 35 punkter redogörs för vad som skulle göras under en femårsperiod, bland annat att öka elevernas läsfärdighet och läslust. I Norge har man också sedan flera år tillbaka ett nationellt centrum för läsning och läsinlärning, Lesesenteret vid universitetet i Stavanger. Här bedrivs såväl grundforskning som praxisorienterad forskning och utvecklingsarbete. På Lesesenteret fanns 31 december 2011'2: "20 faste fagstillinger (bestående av professorer, førsteamanuenser og universitetslektorer), 4 faste administrative stillinger, 3 professor IIer. 13-14 tidsavgrensede stillinger, 4 doktorgradsstipendiater (en 5. vil komme til i løpet av året).”

Centret ansvarar bl.a. för nationella kartläggningar av läsförmågan hos elever i grundskolan, koordination och uppläggning av den norska delen i omfattande internationella läsundersökningar som t.ex. PIRLS. Förutom att utveckla traditionella prov har Lesesenteret också utvecklat material för kvalitativ utvärdering av elevers läsutveckling i alla ämnen och på samtliga stadier, Leselos. Leselos består av ett observationsschema och en omfattande handbok som handlar om vad lärare kan göra för att stötta elevernas utveckling på alla stadier och i alla ämnen. Leselos bygger på kompetensmålen i Kunnskapsløftet och uppmärksammar sex områden som forskningen visat att goda läsare nyttjar i sin läsning: mål med sin läsning, förförståelse, avkodning, ordförråd, läsförståelse och metakognition.

Leselos är en del av vägledningsmaterialet för läsinlärning i skolan, Lesing er. Detta material har delats ut gratis till alla skolor och det finns också att tillgå i pdf format på nätet. På centrets hemsida har man dessutom lagt ut videoinspelade lektioner för att illustrera god praxis, modelläring. Se också Håland, Helgevold, och Hoel (2008).

\section{Svenska strategier}

Sverige har ingen institution som motsvarar det norska "Senter för leseforskning". I viss mån har Svenska Dyslexistiftelsen, som bildades 1989 av Curt von Euler, Ingvar Lundberg och Gunnar Lennerstrand spelat en motsvarande roll i Sverige. Stiftelsens ändamål är att främja och stödja forskning och kunskapsutveckling om läs- och skrivsvårigheter/dyslexi, sprida kunskap om läs- och skrivsvårigheter/dyslexi, bevaka frågor som rör läs- och skrivsvårigheter/dyslexi samt främja de personers intressen som har sådana svårigheter. Genom sina medlemmar företräder stiftelsen spetskompetens om dyslexi inom många olika forskningsområden. Svenska Dyslexistiftelsen har tillsammans med sin systerorganisation Svenska Dyslexiföreningen kommit att bli den viktigaste kraften för att föra ut forskningsbaserad kunskap om dyslexi till 
skolan i Sverige. De vart tredje år återkommande nordiska dyslexikongresserna har spelat en viktig roll i detta sammanhang (Myrberg, 2007).

Det finns också ett svenskt Nationellt centrum för språk-, läs-och skrivutveckling (NCS). Till skillnad från Norge är detta inte förlagt till ett universitet med forskningskompetens på läs- och skrivpedagogik utan på Skolverket. Centret arbetar med elevers språk-, läs- och skrivutveckling. NCS erbjuder kompetensutveckling samt kartlägger och sprider information om aktuell forskning och praktiska erfarenheter inom ämnesfältet.

Under 2011 gav staten 400 miljoner kronor i bidrag för att stärka basfärdigheterna läsa, skriva och räkna. Medlen skulle användas till åtgärder som syftade till att öka elevernas måluppfyllelse. Den prioriterade årsgruppen är elever i årskurs 1-3 som riskerar att inte nå målen men medlen kan även användas till elever i årskurs 4-10 som har behov av särskilt stöd. Det har också startats forskarskolor: Nationell forskarskola i flerspråkighet, litteracitet och utbildning samt Nationella forskarskolan i ungas literacy, flerspråkighet och kulturella praktiker i dagens samhälle (LIMCUL).

\subsection{Slutdiskussion}

I inledningen uppmärksammades det faktum att svenska elevers läsförståelse försämrats signifikant sedan 2000. Allra mest har de svagaste elevernas läsförståelse försämrats. Så är inte fallet i Norge. I denna studie ville jag på basis av en empirisk översikt undersöka vad den svenska och norska forskningen kommit fram till rörande undervisning i läsförståelse i bred bemärkelse.

Låt oss börja med att granska de teoretiska ramverken. Det verkar finnas en större variation bland svenska läsforskare än norska vad det teoretiska ramverket beträffar. En möjlig förklaring kan vara att det finns många smågrupperingar bland de svenska läsforskarna. En annan möjlig förklaring är att den svenska forskningen primärt är kvalitativt orienterad. Kvalitativa studier tenderar att ha större variation i sitt teoretiska ramverk än kvantitativa. I den norska läsforskningen är det lättare att urskilja en kärna. Den norska forskningen förefaller också vara mer teoriprövande än den svenska, dvs. teoretiska begrepp prövas i empiriska studier. Den svenska läsforskningen förefaller mer intresserad av att använda teorin som ett sätt att tolka sina resultat.

En genomgång visar på såväl likheter som olikheter hur forskarna gått till väga för att få fram sin empiri. Här finns omfattande surveyundersökningar med enkäter. De har många fördelar, men man måste, som Bråten (2008) påpekar, tolka resultaten med viss försiktighet. Möjligheten finns till "social desirability", dvs. att många i undersökningsgruppen svarar så som de tror att de förväntas svara. Detta understryker vikten av att utveckla kontextkänsliga metoder för att studera läsning vare sig man gör det med kvantitativ eller kvalitativ metod (jfr. Bråten, 2008) . 
En annan nackdel med enkäterna i dessa surveyundersökningar är att det är mycket vi inte får veta, exempelvis huruvida det (a) råder arbetsro i klassrummen, (b) om lärarna har regelbundna strukturerade textgenomgångar. (c) hur högläsningen sker. Vidare kan man också fråga sig vad en enskild variabel fångar upp.

I ett antal svenska studier har undervisning i läsförståelse undersökts genom att intervjua lärare om deras undervisning (t.ex. Mossberg Schüllerqvist, 2008; Norlund, 2009). Här uppstår ett problem som uppmärksammats av Anmarkrud (2009), Klette (2009) och Lundström (2007), nämligen att vad lärare säger sig göra inte alltid stämmer överens med vad de faktiskt gör i klassrummet. Därför får man tolka de resultat som utkristalliserar sig i intervjustudier med en viss försiktighet.

Samtliga svenska studier som observerat undervisning i klassrummet visar på lärare som lägger ett stort ansvar på den enskilde eleven att ta till sig innehållet $\mathrm{i}$ de texter som läses. Intressant är därför den positiva bild av elevernas läsning som de åtta lärarna i Mossberg Schüllerqvists (2008) studie målar upp. Frågan infinner sig om detta också kommit fram om Mossberg Schüllerqvist gjort egna observationer i klassrummet.

Genom att göra observationer i klassrummet kan forskare iaktta själva läsprocessen. Denna möjlighet finns inte om man nöjer sig med att intervjua eller låta lärare/elever fylla i en enkät.

Det verkar relativt sett vara vanligare med videofilmade observationer i norska studier. Att videofilma har flera fördelar eftersom lärarna kan observera sig själva i aktion. De kan se hur de modellerar lässtrategierna. Forskaren och läraren får vidare möjlighet att tillsammans se på filmerna. De kan frysa vissa moment och tillsammans diskutera dem. Videofilmen ger slutligen såväl forskare som lärare kunskap om huruvida lärarna verkligen tillämpar strategierna så som var avsikten med dem. Videofilmen fångar vidare upp hur länge läraren undervisar i olika moment, taltid, elevturer, längd på elevturer, avbrott, närvaron respektive frånvaron av störande moment. Bevisligen kan man också genom deltagande observation fånga upp mycket men inte lika mycket som flera videokameror. Dessutom har man möjlighet att gå tillbaka och spela upp lektionen (Anmarkrud, 2009). Det finns studier där forskare (Norlund, 2009) drar slutsatser om hur texter kan uppfattas av elever utan att ha testat hur eleverna reagerar på texterna ifråga. Även om forskarens tolkning av texten kan vara rimlig torde ändå viss försiktighet eftersträvas när det gäller (a) implikationer och (b) generalisering av resultaten. Ett mer produktivt tillvägagångssätt torde vara att i likhet med Winje och Aaamotsbakken (2010) också intervjua eleverna. De två forskarna lät elever i årskurs 5 läsa texter om islam i samband med att eleverna intervjuades. Härigenom kombinerar forskarna såväl perception som interaktion.

Låt oss så försöka ge några möjliga förklaringar till de norska resultaten i PISA 2009. En skulle kunna vara implikationer av Kunnskapsløftet. På basis av 
sina intervjudata med lärare och rektorer förhåller sig dock Møller, Ottesen och Hertzberg (2010) skeptiska till detta som en tänkbar förklaring. I deras studie påpekade de intervjuade lärarna att de inte fann så många nyheter i Kunnskapsløftet. Deras svar kan möjligen förklaras med att det är förenat med vissa svårigheter att "uppifrån” på kort tid påverka exempelvis läsundervisningen i skolan. Det tar lång tid innan reformer har satt sig (Cuban, 1990).

Det finns få svenska lässtudier som fokuserat mellanåren och högstadiet. Den svenska forskningen karaktäriseras vidare av den näst intill totala fokuseringen på skönlitterära texter. De norska forskarna har däremot riktat uppmärksamheten på främst mellanåren och högstadiet, dvs. de år då antalet faktatexter intar en alltmer dominerande roll i skolarbetet och då svårighetsgraden på faktatexterna ökar. Eleverna möter mängder av nya såväl ämnesspecifika som allmänspecifika ord. Här finns också sammansatta ord, metaforer och en hög grad av abstraktion i ämnen som matematik, SO eller NO. Men det är inte bara orden utan också själva skriftspråket, syntaxen och all implicit information som finns i läroböckerna. Läroböckerna har således ett krävande språk som förutsätter att eleverna får hjälp med att läsa och välja texter. Detta ställer krav på att lärare har kriterier att gå efter när de väljer texter. Risken är annars överhängande att de väljer texten som har en låg grad av läsbarhet (Lundberg \& Reichenberg, 2009).

Den omfattande norska forskningen rörande faktatexter och vad som gör dem tillgängliga kan ha uppmärksammats av lärare ute på fältet. Om så är fallet kan forskningen ha bidragit till att lärarna avstår från att välja texter som utgör oöverstigliga hinder för eleverna. Detta är dock inte den enda tänkbara förklaringen till de norska resultaten i PISA 2009. Även om lärare utvecklar en kompetens att välja texter med en hög grad av läsbarhet så räcker inte det till att förklara de norska resultaten därför att en text inte kan stå på egna ben. Eleverna behöver också lärare som kan ge dem explicit undervisning i läsförståelsestrategier. För att lärarna ska gå i land med detta behöver de relevanta verktyg. Sådana verktyg har Lesesenteret i Stavanger utvecklat. Här har man utarbetat ett omfattande fortbildningsmaterial, som bygger på kompetensmålen i Kunnskapsløftet. Dessutom har man lagt ut videofilmade modellektioner på centrets hemsida. Detta har sannolikt underlättat för många lärare att ta till sig forskningsrönen och att ge de norska lärarna viktiga redskap att använda i sin undervisning.

Slutligen går det inte att bortse från att de stora norska satsningar som gjorts för att översätta läsdidaktisk forskning till skolpraktik sannolikt har spelat roll för de norska PISA resultaten. Några motsvarande svenska satsningar där man knutit så mycket forskarkompetens till sig finns inte. 


\subsection{Konklusion}

I min forskningsöversikt har jag hittat en del möjliga förklaringar på den fråga jag ställde i inledningen: ”Hur har det kunnat bli så här?” Det skulle dock behövas fler videofilmade klassrumsstudier som exempelvis Anmarkruds (2009) för att undersöka i vilken utsträckning strategiundervisning förekommer i klassrummen. Det räcker dock inte med att videofilma. Det behövs också fler såväl norska som svenska interventionsstudier. Genom att elever får träna upp sin läsförståelse enligt ett strukturerat program så kommer troligtvis andelen svaga läsare att kunna sjunka ytterligare. Interventionsstudier kan också ge kunskap om vilken slags vägledning och uppföljning lärarna har behov av när de ska implementera forskningsbaserad läsundervisning i klassrummet.

Som medborgare förväntas vi ta del av och sätta oss in i en mängd samhällsinformation. Det kan vara allt från att läsa innehållsdeklarationer på livsmedel, läkemedel, det "finstilta" i kontrakt, internet- och mobilabonnemang och andra erbjudanden. Informationen finns dels i pappersform dels på Internet. Studier har visat att texterna inte alltid har en hög grad av tillgänglighet (Lundberg \& Reichenberg, 2009). Detta ställer krav på såväl goda som svaga läsare. Om elever bara "läser texterna på ytan” kan det få förödande effekter. Här behövs det fler studier som undersöker hur kritiskt eleverna läser texter med samhällsinformation och hur tillgängliga texterna är. Min översikt visade på lärare som låter elever arbeta mycket själva. Genom IKT finns idag en ocean av informationskällor att välja bland. Detta ställer stora krav på elevers förmåga att kritiskt välja och granska texter som de kommer i kontakt med inte bara i skolan utan också på fritiden. Här behövs det mer forskning så att inte elever blir exkluderade ur textsamhället.

Min översikt har visat att det genomförts och pågår en omfattande forskning. För att kunna ge alla studier som genomförs i skolpraktiken rättvisa behöver vi också fortsätta utveckla kontextkänsliga instrument (jfr Bråten, 2009).

\section{Tack:}

Jag vill tacka professor Ingvar Lundberg för att han läst mitt manus noggrant och gett mig synnerligen insiktsfulla råd och uppmuntrande kritik.

\section{Referenser}

Anmarkrud, Ø. (2009). Undervisning i lesestrategier og utvikling av lesemotivasjon på ungdomstrinnet: En klasseromsstudie av fire norsklcereres arbeid med forklarende tekst. Avhandling for graden $\mathrm{Ph} \mathrm{D}$. Det utdanningsvitenskaplige fakultet, Universitetet i Oslo.

Anmarkrud, Ø., \& Bråten, I. (2010). Motivation for reading comprehension. Learning and Individual Differences, 19, 252-256.

Andreassen, R. (2008). Eksplisitt leseforståelseundervisning i norske femteklasser. Et felteksperiment. Doktorsavhandling nr 6. Universitetet i Stavanger. 
Andreassen, R., \& Bråten, I. (2011). Implementation and effects of explicit reading comprehension instruction in fifth-grade classrooms. Learning and Instruction, 21, 520 537.

Askeland, N. (2008). Lœrebøker og forståing av kommunikasjon. Om forståing av begrepet kommunikasjon gjennom metaforar og metaforsignal i seks læreverk i norsk for ungdomstrinnet 1997-99. Høgskolen i Vestfold.

Askeland, N., \& Aamotsbakken, B. (2010). ”Lesing av fagtekster i RLE og naturfag i et flerkulturelt miljø”. I D. Skjelbred \& B. Aamotsbakken (red.), Lesing av fagtekster som grunnleggende ferdighet. (431-491).Oslo: Novus forlag.

Asplund, S. (2010). Läsning som identitetsskapande handling [Elektronisk resurs]: gemenskapande och utbrytningsförsök i fordonspojkars litteratursamtal. Diss. Karlstad: Karlstads universitet, 2010. Karlstad.

Beck, I.L., McKeown, M.G., Sandora, C., Kucan., L., \& Worthy, J.(1996). Questioning the Author: A Yearlong Implementation to Engage Students with Text. The Elementary School Journal, 96(4), 385-414.

Bergöö, K. (2005). Vilket svenskämne?: grundskolans svenskämnen i ett lärarutbildningsperspektiv. Diss. Lund : Lunds universitet, 2005. Malmö.

Bommarco, B. (2006). Texter i dialog: en studie i gymnasieelevers litteraturläsning. Diss. Lund: Lunds universitet, 2006. Malmö.

Brink, L. (2006). ”Konsensus om kanon? Kanonbild och ämnesuppfattningar hos 75 litteraturlärare.” I L. Brink \& R. Nilsson (red.), Kanon och tradition. Ämnesdidaktiska studier om fysik-, historie-och litteraturundervisning. Lärarutbildningens skriftserie 2. (13-43). Gävle: Högskolan i Gävle.

Bråten, I., \& Anmarkrud, Ø. (2011). Does naturally-occurring comprehension strategies instruction make a difference when students read expository text? Journal of Research in Reading. Article first published online: 11 APR 2011 DOI: 10.1111/j.14679817.2011.01489.x

Bråten, I. , Strømsø, H.I., \&. Samuelstuen, M.S. (2008). Are sophisticated students always better? The role of topic-specific personal epistemology in the understanding of multiple expository texts. Contemporary Educational Psychology 33, 814-840.

Bråten, I., Strømsø, H. I., \& Britt, M.A. (2009). Trust matters: Examining the role of source evaluation in students' construction of meaning within and across multiple texts. Reading Research Quarterly, 44, 6-28.

Buch Iversen, I. (2010). Betydningen av inferens for leseforståelse. Effekter av inferenstrening. Lesesenter, Stavanger.

Cuban, L. (1990). Reforming Again, Again, and Again. Educational Researcher (19)1, 3-13.

Damber, U. (2010). Reading for life: three studies of Swedish students' literacy development. Diss. (sammanfattning) Linköping: Linköpings universitet, 2010.

Danielsson, K., \& Ekvall, U. (2008). Kemi som skriftspråkspraktik i svenska och finlandssvenska skolor. En projektpresentation. I G. Byrman m.fl. (red.), Rapport från femte nationella konferensen i svenska med didaktisk inriktning i Växjö den 29-30 november. Universitetet $i$ Växjö, 43-54.

Danielsson, K. (2010). Läsa kemi: textanvändning och textsamtal i ett finlandssvenskt klassrum. I I. Eriksson (red.), Innehållet i fokus: kemiundervisning i finlandssvenska klassrum ( 73-120). Stockholm: Stockholms universitets förlag.

Edling, A. (2006). Abstraction and authority in textbooks: the textual paths towards specialized language. Diss. Uppsala: Uppsala universitet, 2006. Uppsala. 
Eikeland, H. (2001). "Utvikling av narrativ kompetanse genom historiefaget i Aschehougs læreverk for ungdomstrinnet”, I S. Selander \& D. Skjelbred, (red.), Fokus på pedagogiske tekster 3: fem artikler om vurdering av lærebøker. (5-31). Tønsberg: Høgskolen i Vestfold 2001. [Elektronisk resurs]

Erixon, P-O. (2010). School subjects paradigms and teaching practice in lower secondary Swedish schools influenced by ICT and media. Computers \& Education, 54, 1212-1221.

Ewald, A. (2007). Läskulturer. Lärare, elever och litteraturläsning i grundskolans mellanår. Lund: Lunds universitet. Lärarutbildningen, Malmö Högskola. Diss.

Fredriksson, U., \& Taube, K. (2001). Läsning bland elever med invandrarbakgrund En undersökning av läsförmåga och bakgrundsfaktorer hos elever i årskurs 3 i Stockholm . Stockholm: Institutionen för internationell pedagogik. Stockholms universitet.

Granström, K., \& Einarsson, C. (1995). Forskning om liv och arbete i svenska klassrum [Elektronisk resurs]: en översikt. Stockholm: Statens skolverk

Hansen, M., \& Lindblad, S. (2010). Forskningskommunikation och publiceringsmönster inom utbildningsvetenskap: En studie av svensk utbildningsvetenskaplig forskning vid tre lärosäten (Vetenskapsrådets Rapportserie Nr 10:2010). Vetenskapsrådet.

Helgevold. (under arbete) Lesestrategier og leseforståelse på mellomtrinnet - en kvalitativ beskrivelse. Universitetet i Stavanger.

Heyl, S. B. (2007). Ethnographic interviewing. I P. Atkinson m.fl. (red.), Handbook of Etnography. (367-383). London: SAGE Publications Ltd.

Hvistendahl, R. (2004a). Læremidler i norsk i den kulturelt komplekse skolen - utfordringer og muligheter. I D. Skjelbred \& B. Aamotsbakken (red.), Fokus på pedagogiske tekster 7. Seks artikler om det flerkulturelle perspektivet i leremidler (25-58). Tønsberg: Høgskolen i Vestfold).

Hvistendahl, R. (2004b). Oversikt over forskning på flerkulturelle perspektiver i lærebøker i norsk og norsk som andrespråk. I D. Skjelbred \& B.Aamotsbakken (red.), Fokus på pedagogiske tekster 7. Seks artikler om det flerkulturelle perspektivet i læeremidler. (7-24). Tønsberg: Høgskolen i Vestfold.

Håland, A., Helgevold, L., \& Hoel, T. (red.), (2008). Lesing er... Stavanger: Lesesenteret UiS. Hägerfelth, G. (2004). Språkpraktiker i naturkunskap i två mångkulturella gymnasieklassrum: en studie av läroprocesser bland elever med olika förstaspråk. Diss. Lund: Univ., 2004. Malmö.

Jönsson, K. (2007). Litteraturarbetets möjligheter: en studie av barns läsning i årskurs F-3. Diss. Lund: Lunds universitet, 2007.

Klette, K. (2009). Challenges in Strategies for Complexity Reduction in Video Studies. Experiences from the PISA+ Study: A video study of teaching and learning in Norway. In T. Janik \& T. Seidel (Eds.), The power of video studies when investigating teaching and learning in classrooms. Münster: Waxmann Publishing.

Knain, E. (2002). Students' interpretations and use of science textbooks in school science discourses. I J. Mikk, V. Meisalo, H. Kukumelk \& M. Horsley (Eds.), Learning and Educational Media. (55-60). The Third Iartem Volume. Tartu: University of Tartu.

Knudsen, S. V., \& A-B. Mortensen Buan (2010). I D. Skjelbred. \& B. Aamotsbakken, (red.), Faglig lesing i skole og barnehage. (77-95). Oslo: Novus forlag.

Knutas, E. (2008). Mellan retorik och praktik: En ämnesdidaktisk och läroplansteoretisk studie av svenskämnena och fyra gymnasielärares svenskundervisning efter gymnasiereformen 1994. Diss. Umeå: Umeå universitet, 2008.

Kuhn, T.S. (1981). De vetenskapliga revolutionernas struktur. [Ny uppl.]. Lund: Doxa. Kunnskapsløftet.

http://www.regjeringen.no/nb/dep/kd/tema/grunnopplaring/kunnskapsloeftet.html?id=141 1 Nedladdat 12 september 2011. 
Lesing er http://lesesenteret.uis.no/leseopplaering/lesing_er/ Nedladdat 19 januari 2012.

Leselos, http://lesesenteret.uis.no/leseopplaering/1._-_4._trinn/article26756-998.html Nedladdat 19 januari 2012.

Liberg, C. (2004). Rörelse i texter. Texter i rörelse. I U. Bäcklund, U. Börestam, U. Melander Marttala \& H. Näslund (red.), Text i arbete. Festskrift till Britt-Louise Gunnarsson, den 12 januari 2005. (106-114) Uppsala: ASLA \& Institutionen för nordiska språk, Uppsala universitet.

Liberg. (under arbete). http://www.did.uu.se/carolineliberg/ Nedladdat 120119

Liberg (under arbete) http://www.did.uu.se/langmathscience/ Nedladdat 120119

Liberg, C., af Geijerstam, Å., \& Folkeryd, J. W. (2011). Scientific Literacy and Students' Movability in Science Texts. In C. Linder, L. Östman, D. A. Roberts, P-O. Wickman, Gaalen Erickson \& A. MacKinnon (Eds.), Exploring the Landscape of Scientific Literacy (74-89). New York: Routledge.

Lie, S., Kjærnsli, M., Roe, A., \& Turmo, A. (2001). Godt rustet for framtida? Norske 15åringers kompetanse $i$ lesing og realfag $i$ et internasjonalt perspektiv. Oslo: Institutt for lærerutdanning og skoleutvikling, Universitetet i Oslo.

Lundberg, I., \& Reichenberg, M. (2009). Vad är lättläst? Härnösand: Specialpedagogiska skolmyndigheten. Andra upplagan.

Lundberg, I., \& Reichenberg, M. ( 2011). Development of reading comprehension among adolescents with mild intellectual disabiliites - An intervention study. Scandinavian Journal of Educational Research. In press.

Lundström, S. (2007). Textens väg: om förutsättningar för texturval i gymnasieskolans svenskundervisning. Diss. Umeå: Umeå universitet, 2007.

Løvland, A. (2010). Faglitterære teksthendingar i klasserommet- i spenningsfeltet mellom Kunnskapsløftets kompetansemål og målet om ” å lese i alle fag” . I Skjelbred, D. \& B. Aamotsbakken, (red.), Faglig lesing i skole og barnehage. (61-76). Oslo: Novus forlag.

Maagerø, E., \& Seip Tønnessen, E. (2006). (red.), Å lese i alle fag. Oslo: Universitetsforlaget.

Maagerø , E., \& Skjelbred, D. (2010). ”De store orda”. Om sammensatte ord i lærebøker og andre fagtekster. I Skjelbred, D. \& B. Aamotsbakken, (red.), Faglig lesing i skole og barnehage. (197-212). Oslo: Novus forlag.

Molloy, G. (2002). Läraren, litteraturen, eleven: en studie om läsning av skönlitteratur på högstadiet. Stockholm: Lärarhögskolan. Doktorsavhandling.

Mossberg Schüllerqvist, I. (2008). Läsa texten eller "verkligheten": tolkningsgemenskaper på en litteraturdidaktisk bro. Diss. Stockholm : Stockholms universitet, 2008. Stockholm.

Myrberg, M. (2007). Dyslexi - en kunskapsöversikt. Vetenskapsrådets rapportserie 2: 2007.

Møller, J., Ottesen, E., \& Hertzberg, F. (2010). Møtet mellom skolens profesjonsforståelse og Kunnskapsløftet som styringsreform. Acta Didactica Norge, 4 (1).

Nationellt centrum för språk-, läs-och skrivutveckling. http://www.skolverket.se/skolutveckling/ncs Nedladdat 19 januari 2012.

Norlund, A. (2009). Kritisk sakprosaläsning i gymnasieskolan: didaktiska perspektiv på läroböcker, lärare och nationella prov. Diss. Göteborg: Göteborgs universitet, 2009.

Nystrand, M. (1997). Opening dialogue: understanding the dynamics of language and learning in the English classroom. New York: Teachers College Press.

Olin-Scheller, C. (2006). Mellan Dante och Big Brother: en studie om gymnasieelevers textvärldar. Diss. Karlstad: Karlstads universitet, 2007. Karlstad.

Pressley, M. (2002). Comprehension strategies instruction. A turn- of- the century status report. In C. Collins Block \& M. Pressley (Eds.), Comprehension Instruction. Researchbased practices (11-27). New York London: The Guilford Press. 
Rasmussen, (2003). Reading literacy performance in Norway: current practice and critical factors. European Journal of Education, 38, 427-443.

Reichenberg, M. (2000). Röst och kausalitet i lärobokstexter. En studie av elevers förståelse av olika textversioner. Acta Universitatis Gothoburgensis. Gothenburg Studies in Educational Science, 149. Doktorsavhandling.

Reichenberg, (2003). Är lättlästa texter verkligen lättlästa? I Språk och lärande. Rapport från ASLA:s höstsymposium Karlstad, 7-8 november 2002. (74-92). Uppsala: Svenska föreningen för tillämpad språkvetenskap.

Reichenberg, M. (2008a) "But before you said you believed that...” A longitudinal study of text talks in small groups. The Reading Matrix, 8, 158-185.

Reichenberg, M. (2008b). Making Students Talk About Expository Texts. Scandinavian Journal of Educational Research, 52, 17-39.

Reichenberg, M. (2010). Elever i gymnasiesärskolan läser och samtalar kring lättlästa texter. I D. Skjelbred \& B. Aamotsbakken (red.), Faglig lesing i skole og barnehage. (97-121). Oslo: Novus forlag.

Reichenberg, M., \& Wadbring, I. (2008).”Have they pinched it from another newspaper?” Designs for learning, 2/08.

Rosén, M., Myrberg, E., \& Gustafsson, J-E. (2005). Läskompetens i skolår 3 och 4. Nationell rapport från PIRLS 2001 i Sverige. Acta Universitatis Gothoburgensis, Göteborg Studies in Educational Sciences 236.

Samuelstuen, M. S. (2005). Cognitive and metacognitive strategy use with a particular focus on text learning. [In Norwegian: Kognitiv og metakognitiv strategibruk med scrlig henblikk på tekstlcring. En empirisk studie av strategibruk hos 10. klasseelever og a) relasjonene til leseprestasjoner, leseformål, forkunnskaper og ordavkoding og b) psykometriske egenskaper knyttet til elevenes selvrapporteringer.] Doctoral thesis. [Dr. polit.-avhandling]. Faculty of Social Sciences and Technology Management, NTNU.

Samuelstuen, M., S., \& Bråten, I. (2005). Decoding, knowledge, and strategies in comprehension of expository texts. Scandinavian Journal of Psychology. 46/2. 107-117.

Schmidl, H. (2008). Från vildmark till grön ängel: receptionsanalyser av läsning i åttonde klass. Diss. Uppsala : Uppsala universitet, 2008. Göteborg.

Seip Tønnesen, E. (2010). Sakprosa for begynnere. I B. Aamotsbakken \& D. Skjelbred, (red.), Faglig lesing i skole og barnehage. (213-234). Oslo: Novus forlag.

Selander , S. (2010). Läsa för att lära. I B. Aamotsbakken \& D. Skjelbred (red.), Faglig lesing i skole og barnehage. (165-180). Oslo: Novus forlag.

Siljan, H. (2011). Metaforisering, nominalisering og normering-en teoretisk studie av grammatisk metafor og to empiriske undersøkelser av språktrekket i læreboktekster Universitetet i Oslo. Diss.

Skjelbred, D., \& Aamotsbakken, B. (red.), (2010). Projektet Lesing av fagtekster som grunnleggende ferdighet, I Lesing av fagtekster som grunnleggende ferdighet (9-29). Oslo: Novus forlag.

Solheim, R., \& Tønnesen, F.E. (2003). Hvorfor leser klasser så forskjellig? En sammenligning av de 20 klassene med de beste og de 20 klassene med de svakeste leseresultatene i PIRLS 2001. Stavanger: Senter for leseforskning.

Skolverket. (2007). Vad händer med läsningen? En kunskapsöversikt om läsundervisningen i Sverige 1995-2007. Rapport 304. Stockholm: Fritzes förlag.

Skolverket. (2010). Rustad att möta framtiden? Rapport 352. Stockholm:Fritzes förlag. Solheim, R. , \& Tønnesen, F.E. (2003). Hvorfor leser klasser så forskjellig? Centre for Reading Research, Stavanger University College. 
Stenlund, K. (2011). Läsning på mellanstadiet. En studie med fokus på elevers läsförmåga. Institutionen för pedagogik och didaktik. Forskarskolan i läs-och skrivutveckling. Stockholms universitet.

Svenska dyslexistiftelsen. http://dyslexistiftelsen.se/ nedladdad 120119

Tengberg, M. (2011). Samtalets möjligheter: om litteratursamtal och litteraturreception $i$ skolan. Diss. Göteborg: Göteborgs universitet, 2011.

Tjernberg, C. (2011). Specialpedagogik i skolvardagen: en studie med fokus på framgångsfaktorer i läs- och skrivlärande. Lic.-avh. Stockholm: Stockholms universitet, 2011

Thorson, S. (2005). Den dubbla receptionen: om litteratursamtal mellan elever och deras svensklärare. Göteborg: Litteraturvetenskapliga institutionen, Göteborgs universitet.

Torvatn, A. C. (2002) Tekststrukturens innvirkning på leseforståelsen: en studie av fire lareboktekster for ungdomstrinnet og sju elevers lesing av dem. Avhandling (dr. art.) Norges teknisk-naturvitenskapelige universitet, Trondheim, 2003

Ullström, S. (2002). Likt och olikt: Strindbergsbildens förvandlingar i gymnasiet. Diss. Lund : Univ., 2002. Eslöv.

Van Daal. V., Solheim, R.G., Gabrielsen, N.N., \& Bergnum, A.C., (2007). Norske elevers leseinnsats og leseferdigheter: Resultater for fjerde og femte trinn i den internasjonale studien PIRLS 2006. Stavanger: Senter for leseforskning.

Wasik, B. A., \& Slavin, R. E. (1993). Preventing early reading failure with one-toone tutoring: A review of five programs. Reading Research Quarterly 28, 179-200.

Wedin, Å. (2006). Etnografisk lingvistik i utbildningsforskning. Nordand. Nordisk tidskrift för andraspråksforskning (1), 71-88.

Winje, G., \& Aamotsbakken, B. (2010). Å lese om islam og andre emner i RLE på 5. årstrinn. I B. Aamotsbakken \& D. Skjelbred (red.), Faglig lesing i skole og barnehage. (123-140). Oslo: Novus forlag.

Aamotsbakken, B., \& Skjelbred, D. (red.), (2010). Forord. I Faglig lesing i skole og barnehage. (5-6). Oslo: Novus forlag.

Aamotsbakken, B., Askeland, N., Maagerø, E., Skjelbred, D., \& Torvatn, A. C. (2005). Vurdering av læeremidler med fokus på et flerkulturelt perspektiv. Rapport 2/2005. Tønsberg: Høgskolen i Vestfold.

Österholm, M. (2004). Läsa matematiska texter: förståelse och lärande i läsprocessen. Linköpings universitet. Linköping studies in science and technology. Thesis 1134.

${ }^{1}$ Läsförståelse definieras i denna artikel i enlighet med PISA 2000, 2003, 2006 och 2009: Förmåga att förstå, använda och reflektera över texter för att uppnå sina egna mål, utveckla sina kunskaper och sin potential och för att delta i samhället. I PISA 2009 finns dessutom ett tillägg om läsengagemang: "Förmåga att förstå, använda, reflektera över och engagera sig i texter för att uppnå sina egna mål, utveckla sina kunskaper och sin potential och för att delta i samhället "(Skolverket, 2010, s. 29).

${ }^{2}$ Åse Kari Wagner, personlig kommunikation, 18 januari 2012. 